\title{
Perceptive-Motor Maturity and its Relations with Planning, Memory Immediate and Non-Verbal Intelligence
}

\author{
Fernanda Otoni ${ }^{1}$ \\ Fabián Javier Marin Rueda ${ }^{2,3}$ (ID)
}

\begin{abstract}
The acquisition of new knowledge depends on the interaction of diverse ability that can facilitate the cognitive processes that underlie learning. The aim of this paper is to verify the relationship between perceptive-motor maturity and planning, visual perception, immediate memory, and non-verbal intelligence, as well as how age and perceptive-motor maturity can predict performance in these variables. Therefore, we used the screening version of the Bender test - Gradual Scoring System, Rey Complex Figure Test, and Human Figure Drawing - Sisto scale. The study included 693 children whose ages range from 6 to 10 years $(M=8.42 ; D P=1.38)$. The results presented statistically significant correlations between all the instruments, indicating that the more developed visual perception and motor coordination, the biggest is the probability that children have succeed in tasks that depend of planning skills, the ability to retain and process information, and the conceptual repertoire.
\end{abstract}

Keywords: psychological testing, childhood development, cognitive development, neuropsychological assessment

\section{Maturidade Perceptomotora e suas Relações com Planejamento, Memória Imediata e Inteligência Não Verbal}

\begin{abstract}
Resumo: A aquisição de novos conhecimentos dependem da interação de diversas habilidades que podem facilitar os processos cognitivos que são subjacentes à aprendizagem. Assim sendo, objetivou-se verificar a relação da maturidade perceptomotora com o planejamento, a percepção visual, a memória imediata e a inteligência não verbal, bem como verificar o quanto a idade e a maturidade perceptomotora podem predizer o desempenho nessas variáveis. Para tanto, utilizou-se a versão de rastreio do Bender - Sistema de Pontuação Gradual, as Figuras Complexas de Rey e o Desenho da Figura Humana - Escala Sisto. Fizeram parte do estudo 693 crianças com idades entre seis e 10 anos $(M=8,42 ; D P=1,38)$. Os resultados indicaram que quanto mais desenvolvida a percepção visual e a coordenação motora, maior a probabilidade de as crianças obterem êxito nas tarefas que dependem do planejamento, da capacidade de reter e processar informações e do repertório conceitual.
\end{abstract}

Palavras-chave: testes psicológicos, desenvolvimento infantil, desenvolvimento cognitivo, avaliação neuropsicológica

\section{La Madurez Perceptiva Motora y sus Relaciones con la Planificación, la Memoria Inmediata y la Inteligencia no Verbal}

\begin{abstract}
Resumen: La adquisición de nuevos conocimientos depende de la interacción entre diferentes habilidades que pueden facilitar los procesos cognitivos que subyacen en el aprendizaje. Este estudio tuvo como objetivo constatar la relación entre la madurez perceptiva motora y la planificación, la percepción visual, la memoria inmediata y la inteligencia no verbal, así como verificar cuánto la edad y la madurez perceptiva motora pueden predecir el rendimiento en estas variables. Para tal, se utilizó la versión de rastreo del Bender -Sistema de Puntuación Gradual, las Figuras Complejas de Rey y el Dibujo de la Figura Humana- Escala Sisto. Participaron en el estudio 693 niños con edades entre 6 y 10 años $(M=8,42 ; D T=1,38)$. Los resultados mostraron que cuanto más desarrollada la percepción visual y la coordinación motora, mayor es la probabilidad de que los niños tengan éxito en las tareas que dependen de la planificación, de la capacidad de retener y procesar informaciones y del repertorio conceptual.
\end{abstract}

Palabras clave: tests psicológicos, desarrollo infantil, desarrollo cognitivo, evaluación neuropsicológica

${ }^{1}$ Universidade São Francisco, Campinas-SP, Brazil

${ }^{2}$ Universidade São Francisco (USF), Campinas-SP, Brazil

${ }^{3}$ Centro Universitário de Brasília (UniCEUB), Brasília-DF, Brazil

Article derived from the master's dissertation of the first author under the supervision of the second, defended in 2018, in the Graduate Program in Psychology, area of concentration in Psychological Assessment at Universidade São Francisco. Support: This study was financed in part by the Coordenação de Aperfeiçoamento de Pessoal de Nível Superior - Brasil (CAPES) - Finance Code 001.

Correspondence address: Fernanda Otoni. Universidade São Francisco. Rua Waldemar César da Silveira, 105, Vila Cura D’Ars, Campinas-SP, Brazil. CEP 13.045-510. E-mail: fer_ottoni@hotmail.com
The screening version of the Bender test - Gradual Scoring System aims to assess the perceptomotor maturity of an individual by reproducing the drawing of three gestalt figures (Rueda, Sousa, Santos, \& Noronha, 2016). Understood as the ability to perceive, integrate external stimuli and reproduce them in a motor action, this ability has been related to several cognitive aspects, such as visual perception, attention, memory, praxis, temporal and spatial concepts, organization and motor coordination (Bender, 1955; Koppitz, 1989; Rueda et al., 2016; Sisto, Noronha, \& Santos, 2006). Because it represents the 
principles of Gestalt, proximity, similarity and closure, the activity proposed by the Bender test is not a simple task, as it is necessary to stick to both the structure and the forms of the stimuli, composed of points or loops, straight lines, curves and angles. Thus, seeing and reproducing figures requires the development and interaction of several cognitive skills that can enable and favor responses addressed to an objective (Bender, 1955).

According to Fuentes, Malloy-Diniz, Camargo and Cosenza (2014), from the stimuli extracted from the environment, a flow of sensory information is transmitted and transformed into different processing units, allowing the construction of a concrete image. In this perspective, Koppitz (1989) considers that perceptual motor maturity does not depend on chronological age, but on a series of cognitive functions that converge with the emergence of specific motor activities that change as the child matures and, therefore, is a subjective and individual process. As it is a process that improves throughout childhood, Bender (1955) suggests that it is around the age of five that the child is able to identify the shapes of the figures in the Bender test and sketch some traces. A reproduction similar to the original model of the figures tends to happen near adolescence, when formal thought is acquired.

Because it is one of the most primitive functions of human beings and it has an evolutionary character, several studies indicate that perceptual maturity would be a facilitator in the performance of tasks that depend on planning, immediate memory and non-verbal intelligence (Batista \& Gonçalves, 2016 ; SLZR Silva, Oliveira, \& Ciasca, 2017; Suehiro, Santos, \& Rueda, 2015). According to S. L. Z. R. Silva et al. (2017) the cognitive skills, which are underlying the reproduction of the figures of the Bender test, are also associated with the learning process, as both activities require the child to understand, organize, store and evoke the most relevant information that will later be directed to perform an action.

Another psychological instrument that also encompasses several cognitive skills underlying perceptual motor maturity are Rey Complex Figures Test (Rey test) (Alves \& Brito, 2007; S. L. Z. R. Silva et al., 2017). The application of this test is carried out in two moments, in which it is possible to evaluate the planning ability, visual perception and immediate memory. M. S. Oliveira and Rigoni (2010) affirm that the planning of the reproduction of the image of the Rey test as a whole would allow a greater capacity of absorption of the details of the figure, and consequently would favor the memory of its most important part. However, this planning is a consequence of how the stimulus was perceived visually, as it is the visual perception that will influence the entire process of reproducing the drawing. In order to draw, the child needs to recover information that it has already learned and perceived, therefore, which evidences the importance of memory in the processing of visual activities (Alves \& Brito, 2007; Cruz, Toni, \& Oliveira, 2011; MS Oliveira \& Rigoni, 2010 ).

According to Cruz et al. (2011), in addition to the interaction of several cognitive skills, the performance in the Rey test also involves a maturational aspect, since it is according to its development that the child acquires planning strategies that enable him or her to give more accurate answers. For Alves and Brito (2007), Cruz et al. (2011) and AM Silva, Peçanha, Charchat-Fichman, Martins and Correa (2016) children with ease in perceiving the figure from its general structure tend to present better planning strategies, and consequently improve the reproduction performed by memory of the figure. A.L.S. Oliveira et al. (2016) applied the B-SPG and the Rey test to 83 children, aged seven to ten years. The results of this study showed moderate and statistically significant correlations between the B-SPG and the copy task of the Rey test $(\mathrm{r}=-0.55)$, and the task that evaluates memory $(r=-0.44)$. The authors suggest that the greater the ease with which children perceive external stimuli and reproduce it in an action, the greater the tendency to perform well in tasks that depend on organization, planning, and recall of memory. Thus, it can be understood that information tends to be remembered the way it is perceived and that it can also impact decision making and task execution. It is important to assess the cognitive skills that involve the ability to recognize, solve problems, and make decisions to perform an action (Baddeley, Anderson, \& Eysenck, 2011; Sisto, 2005; Suehiro \& Cardim, 2016).

According to A. B. Sousa and Salgado (2015), these skills involve the ability to understand and encode the received information, which will later be associated with previous experiences, in order to promote the evocation of memories that will favor the elaboration of decision making, thus allowing the formation of complex thought structures. To assess these capabilities, several authors use the Human Figure Design (HFD), which is considered as an estimator of non-verbal intelligence (Bartholomeu, Cecato, Montiel, Machado, \& Sisto, 2012; S. L. Z. R. Silva et al., 2017). In HFD, non-verbal intelligence is assessed by the ability to associate, the memory of details, discrimination, spatial orientation, analysis, abstraction and visuomotor coordination (Sisto, 2005).

Sisto (2005) recommends that from the reproduction of a person's drawing, the child is able to represent the concept of a human being through the elaboration of its parts. It is considered that there is a great intellectual component in the act of drawing, because when younger it is common for the child's drawing to be based on what it knows and not on what is perceived. Thus, only when it is able to differentiate the external parts of the human body and name them does the child manage to represent them as they are seen (Carreras, Uriel, \& Fernández Liporace, 2013; Clarke, McAneney, Chan, \& Maguire, 2018). Therefore, it can be said that when the child draws, it is not only expressing his artistic ability, but part of his conceptual repertoire. In this perspective, the conceptual repertoire tends to be a reliable indicator of intelligence, since the increase in concepts would boost children's cognitive capacity, enhancing the integration of perceived objects and consequently enriching the quantity and quality of responses (Araújo \& Fernandes, 2015 ; K. S. Oliveira\&Wechsler,2016;Picard,2015).Carrerasetal.(2013), 
in turn, suggest that throughout maturation, the child improves its ability to perceive similarities and differences, not only of the human body, but of the entire environment that surrounds it.

According to Bartholomeu et al. (2012), children who tend to make less distortion errors in the reproduction of the B-SPG figures, tend to include more details in the HFD, indicating that a well-developed perceptual maturity could be a facilitated component in tasks that depend on non-verbal intelligence. S. L. Z. R. Silva et al. (2017) still suggest that performance in the HFD would also be related to the learning process, as children with school difficulties do not perform well when asked to draw the human figure. It is believed that the fact that the child has difficulties in differentiating, categorizing, and reproducing the parts of the drawing would also be linked to the ability to retain and associate the school content, thus making it difficult to apprehend new knowledge (Sisto, 2005).

In view of the above, perceptual maturity, planning, immediate memory recall, and non-verbal intelligence are the result of the interaction of several cognitive skills that tend to consolidate according to the cognitive development of each child (A. L. S. Oliveira et al., 2016; Rueda et al., 2016; Suehiro et al., 2015). When well developed, visual perception and motor coordination tend to favor the acquisition of new knowledge and facilitate cognitive processes that underlie learning (Alves \& Brito, 2007; Bartholomeu et al., 2012; Cruz et al., 2011; AM Silva et al., 2016; SLZR Silva et al., 2017). Therefore, this paper aimed to verify the relationship between perceptual motor maturity and planning, visual perception, immediate memory, and non-verbal intelligence, as well as verify how age and perceptual motor maturity can predict performance in these variables.

\section{Method}

\section{Participants}

693 children (52.7\% were girls) from the states of São Paulo and Minas Gerais, enrolled from the first to the fifth year of Elementary School, aged between six and ten years $(M=8.42 ; S D=1.38)$ participated in the study . The group of six-year-old children was composed of 75 participants $(10.8 \%)$, the seven-year-old group had 141 (20.3\%), while the group of eight-year-old children was formed by 113 children $(16.3 \%)$, the group with nine years old had 124 participants (17.9\%) and, finally, the group of participants with ten years old had the largest number, 240 (34.6\%). The discrepant number of children in the six and 10-yearold group is justified by the fact that data collection was carried out in the classroom, considering the school year. In observing the children's protocols, we found that most of the first-year students had already completed seven years, while the fourth-year children had already completed ten years.

\section{Instruments}

Screening version of the Bender Visual-motor Gestalt Test: Gradual Scoring System (B-SPG) (Rueda et al., 2016). The screening version of Bender B-SPG (Rueda et al., 2016) is a proposal that comes from the gradual score correction system developed by Sisto et al. (2006), who used nine figures to assess perceptual motor maturity. In this version, figures $3,4,7 \mathrm{a}$ and $7 \mathrm{~b}$ are used, whose scores ranges from zero to two points. When evaluating the distortion errors of the form, a zero score is accepted only when there are no errors. A score of one and two is assigned according to the quality of the drawing and presence of distortions in it. The maximum score that can be achieved on this instrument is eight, which indicates total distortion of the four copied figures. To perform the test, the child is asked to reproduce the figures on a blank sheet. In the collective application the figures are projected on a white screen and, in individual applications, the child is presented with one card at a time. Through factor analysis, the authors of this system found that the figures that make up the screening version explain $80 \%$ of the variance of the total B-SPG score and, therefore, it presents a good estimate for assessing perceptual motor maturity.

Rey Complex Figure Test (M. S. Oliveira \& Rigoni, 2010). The Rey complex figures test assess visual perception, planning and immediate memory. The instrument consists of two complex figures in terms of quantity and presentation of stimuli. Figure A, being the most complex, is indicated for people from eight years old and above, while Figure $\mathrm{B}$ is administered to children between the ages of four and seven. However, the authors of the test admit that for a better visibility on the construction of the shapes of the drawing, Figure A can also be applied to younger children. Since the present study was applied collectively and for the planning to be centralized, this guidance was implemented. The application of the test consists of two moments, in which the first part allows planning and visual perception, and later the immediate memory is evaluated. According to M. S. Oliveira and Rigoni (2010), planning refers to the ability to mentally trace a path to another in order to perform an action. In this perspective, when presenting the figure and asking the child to make a copy as similar as possible, it is indicated that during the reproduction some changes of colored pencils will be carried out. This process allows to verify how the child plans mentally to organize itself and start the structure of the drawing. In the second part, the visual stimulus is removed and it is requested a copy of the figure from immediate memory, which in general refers to the ability to retain and process the information to perform an action (M. S. Oliveira \& Rigoni , 2010). The instrument was corrected based on its manual. Each unit received a score between zero and two points, involving the quality and the proper location of the shape. The maximum score in each of the figures is 36 points, which indicates total precision 
in the reproduction and detailing of the elements present. The precision studies of the internal consistency of Figure A showed internal consistency $(\alpha)$ of 0.86 for the copy and 0.81 for the memory, signaling a good estimate of the test's reliability (M. S. Oliveira \& Rigoni, 2010).

Human Figure Drawing - Sisto scale (Sisto, 2005). The HFD is a non-verbal intelligence test, adapted for the Brazilian population by Sisto (2005). According to the author, the drawing of a human person can be a measure for assessing the children's intellectual capacity. In the application instruction, the child is asked to draw a human figure in as much detail as possible. Sisto determines that the drawing should be corrected only if it has the head, arms and legs. Once this criterion is met, it is observed 30 indicators that follow a pattern of difficulty. For the correction, one point is assigned to the presence of each of these items and zero to the absence. The general score is obtained by the total sum of the items. Therefore, the maximum score that a child can obtain in this test is 30 points. Accuracy estimates provided internal consistency $(\alpha)$ of 0.87 for the male scale and 0.82 for the female scale, indicating that the precision of the scale was satisfactory with good consistency between the items and that the instrument is valid for measuring the intellectual level of children according to their maturation development.

\section{Procedures}

Data collection. After the delivery and return of the Free and Informed Consent Terms (FICT) of the students, data collection was carried out collectively in a single application of approximately 30 minutes. The classrooms had an average of 20 children, in which all responded to the three instruments. Those whose age was not between six to 10 years of age had the protocols excluded. After establishing a rapport in which the objectives of the instruments were presented and the children were asked to fill in their name, age and school year, the children received a black pencil and a colored pencil and four sheets of A4 bond paper. The colored pencil was used only for the execution of the copy figure of Rey figures. The children started the drawings of Rey complex figure test, followed by the Bender Test, and finally, the HFD test - Sisto scale.

For the reproduction of the first drawing of Rey figures, children were asked to start drawing with colored pencils. According to M. S. Oliveira and Rigoni (2010), people who take too long or draw too fast tend to stick to one or the other element and end up committing more omissions or distortions in the location of the strokes. The authors affirm that between two to six minutes is a time considered normal for children aged six to ten years. So, by considering that some children could finish the drawing ahead of schedule, we estimated forty seconds to the use of colored pencil and the remaining time was used to continue the drawing with the black pencil. As this was a collective application and there was not much available time with the students, it was stipulated that the children would have up to six minutes to make each drawing of the Rey figures. The interval time for the reproduction of the copy figure for the figure of memory was three minutes. As for the Bender test and the HFD - Sisto Scale, a time limit was not stablished, as they are relatively simpler and faster instruments.

Data analysis. Descriptive statistics were performed using Statistical Package for the Social Sciences v. 21 (SPSS), to better characterize the sample and describe the participants' means in relation to each of the instruments. The assumptions for the application of parametric analyzes were also verified, showing normality of the data through acceptable levels of kurtosis distribution and asymmetry (Hopkins \& Weeks, 1990). After verifying that the data in this sample were suitable to parametric analysis, Pearson's correlation coefficient $(r)$ was determined to verify the relationship between the screening version of B-SPG and the other instruments.

In the sequence, using the Mplus v. 7 program, we sought to verify the predictive power of the screening version of B-SPG in the performance of Rey Complex Figures Test and the Human Figure Drawing - Sisto Scale. For this analysis, the Path Analysis technique was used (VanderWeele, 2016), using the Robust Maximum Likelihood method (Muthén \& Muthén, 2019). The same technique was used to evaluate the predictive power of age in the performance of all used instruments. It is considered that the models proposed to carry out the Path Analysis are not intended to establish a single cause and effect relationship, but rather to present an empirical basis, testing the relationship between the instruments used.

\section{Ethical Considerations}

After the schools' authorization, the present study was submitted to the Research Ethics Committee of Universidade São Francisco in accordance with Resolution 196/96 of the NationalHealth Council(CAAENo. 73102617.1.0000.5514), and only after its authorization the data collection began.

\section{Results}

The objective of this study was to verify the relationship between perceptual motor maturity and its relationship with planning, immediate memory and non-verbal intelligence. Initially, for greater reliability of the results obtained in this study, the instruments used were corrected by two psychologists with expertise in their evaluation criteria. The analysis between both evaluators indicated a statistically significant correlation $(p<0.001)$ and strong magnitude for the screening version of the B-SPG $(r=0.90)$, for the Rey Complex Figures Test $(r=0.94)$ and for the HFD test $(r=0.93)$. These results indicated precision among the evaluators, suggesting that this research has no bias in the interpretation of the evaluation criteria.

Inferential statistics were performed in order to verify the overall average of the participants in each of the instruments. 
Regarding the Bender test, it was observed that only $2.3 \%$ of children $(n=16)$ did not make any distortion errors when reproducing the Bender figures, and 5.9\% $(n=41)$ were unable to draw properly none of the drawings. The children's average was 4 points $(S D=2.04)$. Regarding the planning evaluated by the Rey Figures test, it was observed that $33.5 \%$ of the children $(n=232)$ drew the figure starting with the general outline, without differentiating the details of the main rectangle. The other $23.2 \%(n=161)$ of children started drawing by the parts, gradually including the traces that permeate the rectangle to finish it, and $16 \%(n=111)$ of them did not plan a structure to start the drawing, as they did the drawing with juxtaposition of details. With regard to visual perception, the average score of children was 20.39 $(S D=8.39)$, with only one participant having the minimum score and the other the maximum. In the reproduction of the figure by memory, eight children did not score any points, only one reached the maximum score, and the average score was $12.27(S D=6.97)$. Finally, seven children scored only one point on the HFD test - Sisto scale and only one scored the maximum. The average score when reproducing the drawing of a human person was $13.73(S D=6.13)$.

There was a correlation between the total score in the screening version in the B-SPG with the Rey Complex Figures and the HFD and, subsequently, it was verified the correlation between instruments improves as age increases. The results of this correlation with age control can be seen in Table 1 .

Table 1

Correlation Between the Screening Version of B-SPG as the Other Instruments

\begin{tabular}{lccccc}
\hline Measures & Age & & Copy (Rey) & Memory (Rey) & HFD \\
\hline & $6-10$ & $r$ & $-0.50^{* *}$ & $-0.40^{* *}$ & $-0.49^{* *}$ \\
& 6 & $r$ & -0.19 & -0.02 & -0.23 \\
Screening & 7 & $r$ & $-0.38^{* *}$ & $-0.32^{* *}$ & $-0.33^{* *}$ \\
B-SPG & 8 & $r$ & $-0.24 *$ & $-0.20^{*}$ & $-0.35^{* *}$ \\
& 9 & $r$ & $-0.33^{* *}$ & $-0.26^{* *}$ & $-0.34^{* *}$ \\
& 10 & $r$ & $-0.38^{* *}$ & $-0.28^{* *}$ & $-0.37 * *$ \\
\hline
\end{tabular}

Note. ${ }^{*} p<0.005 ; * * p<0.001$.

The results in Table 1 indicated that the correlations were all significant, negative and of moderate magnitude (Cohen, 1988), showing that as the distortion errors in the B-SPG decrease, the children tend to do better in the tasks of Rey Complex Figures Test and HDF test - Sisto scale. When considering the ages, the results indicated that except for the group of six-year-old children, the others showed statistically significant, negative and weak correlations. It is evident that as the distortion errors in the reproduction of the figures of the Bender test decrease, the better the performance in the tasks that depend on memory and non-verbal intelligence. Subsequently, the path analysis technique was performed to verify how much the screening version of the B-SPG could predict the performance in Rey Complex Figures Test and in the HDF test - Sisto scale, whose results are shown in Table 2 .
Table 2

Regression using the Screening Version of B-SPG as Dependent Variable

\begin{tabular}{lllcc}
\hline Explanatory variable & & Dependent variable & $\beta$ & $p$ \\
\hline & $\rightarrow$ & Copy Type (Rey) & 0.18 & $<0.001$ \\
Screening & $\rightarrow$ & Copy Task (Rey) & -0.26 & $<0.001$ \\
B-SPG & $\rightarrow$ & Memory Task (Rey) & -0.17 & $<0.001$ \\
& $\rightarrow$ & HFD -Sisto Scale & -0.24 & $<0.001$ \\
\hline
\end{tabular}

The results presented in Table 2 indicate that the observation of the type of copy that the child makes in the Rey test and the tasks that evaluate the visual perception and memory of the Rey Complex Figures Test with the Human Figure Drawing were predicted by the screening version of the B-GSS, and that the estimated regressions for this model showed a Beta value between -0.26 and -0.17 . It was also found that the screening version of the B-SPG is capable of predicting $25 \%$ of the performance in the copy task of Rey Complex Figures and 25\% of the HFD, followed by $18 \%$ of the child's planning and $17 \%$ of prediction of performance in the memory task of the Rey test. Since age is an important variable for children's cognitive development, a path analysis was performed considering age as an independent variable and the dependent variables were the screening version of the B-GSS, the tasks of Rey Complex Figures Test and the HFD test - Sisto scale. The results of this analysis is presented at Table 3.

Table 3

Estimated regression using age as a dependent variable

\begin{tabular}{clcc}
\hline $\begin{array}{c}\text { Explanatory } \\
\text { variable }\end{array}$ & \multicolumn{1}{c}{ Dependent variable } & $\beta$ & $p$ \\
\hline & $\rightarrow$ Screening version of B-SPG & -0.36 & $<0.00$ \\
& $\rightarrow$ Copy Type (Rey) & -0.25 & $<0.001$ \\
Age & $\rightarrow$ Copy Task (Rey) & 0.27 & $<0.001$ \\
& $\rightarrow$ Memory Task (Rey) & 0.18 & $<0.001$ \\
& $\rightarrow$ Human Figure Drawing & 0.23 & $<0.001$ \\
\hline
\end{tabular}

Initially, it was observed that age is able to predict the performance of all instruments used in this research. It was also found that age has a greater predictive power in tasks that depend on visual perception and planning, which are evaluated by the copy task of Rey Complex Figures (27\%) and by the screening version of the B-SPG (36\%). Another observation was that age is able to predict $23 \%$ of how children plan to perform a task. Regarding the conceptual repertoire evaluated by the HFD test - Sisto scale, age is capable of predicting $23 \%$ of performance and, finally, for the task performed in memory of the Rey Complex Figures Test, the age prediction power is $18 \%$. The results also indicates that the screening version of the B-SPG is the most affected in this model, as for each increase of one standard deviation in age, perceptual maturity decreases 0.36 standard deviation. It is important to bear in mind that the screening version of the B-SPG scores the errors, so the lower the 
score, the better the performance on the test. The older the age, the lower the distortion errors made in the reproduction of the figures. In the same sense, the memory task is the least affected by age, with only 0.18 standard deviation.

\section{Discussion}

This study aimed to evaluate the relationship between perceptual motor maturity and planning, immediate memory and non-verbal intelligence. For this purpose, the screening version of the B-GSS, the Rey Complex Figures Test and the HDF test - Sisto scale were used. The results of inferential statistics indicated that the performance averages in most children were as expected for each age (M. S. Oliveira \& Rigoni, 2010; Sisto, 2005; Sisto et al., 2006). A point to be highlighted is that although the Rey Complex Figures Test is not a standardized instrument for collective application, two exchanges of colored pencils were carried out, which allowed us to verify that there was a tendency for children to reproduce the copy of the figure, starting the drawing by the details. According to Cruz et al. (2011), children with difficulties in planning the drawing from the whole may have difficulty in remembering various elements of the figure.

The correlation between the reproduction of the figures in the screening version of the Bender test and the tasks proposed by the Rey Complex Figures Test allowed us to show that as the distortion errors in the B-SPG decrease, the more chance the children have to do better in activities that depend on planning and immediate memory. Such findings corroborate the study by A. L. S. Oliveira et al. (2016) who found similar results when verifying that well-developed visual perception tends to facilitate the processes of other cognitive skills. In this perspective, it was observed in the present study that the better the perceptomotor maturity, the greater details were attributed to the drawing of the human figure. Like Bartholomeu et al. (2012), it is hypothesized that the ability to perceive external stimuli with minimal distortions contributes to increasing the conceptual repertoire of children.

When considering the ages to correlate the instruments, it was observed that except for the group of children aged six, the other age groups showed statistically significant correlations. This data suggest that the perceptomotor maturity can favor a better performance in the tasks of the Rey test and in the HFD - Sisto scale. These results indicate that the cognitive skills underlying visual-motor ability are also related to tasks that depend on planning, immediate memory and non-verbal intelligence. In this perspective, Alves and Brito (2007) point to the importance of visual perception as a facilitator for the development of the ability to select, name and represent external stimuli in order to execute responses with a certain objective. Regarding that the correlations between the instruments were not significant for the six-year-old group, it can be hypothesized that at this age the cognitive skills required in the reproduction of these drawings have not yet been consolidated, since both the figures that make up the screening version of B-SPG and the Rey Complex Figure test have a high level of difficulty. In the HFD test - Sisto scale it was found that most children in this group did not present the details that make up the most difficult parts of the human figure.

It was also found that the task of copying the Rey Complex Figure test was the activity that had the greatest impact on perceptual motor maturity. These findings were already expected, as both the screening version of the B-SPG and the first task of the Rey Complex Figure test evaluate visual perception. However, it is noteworthy that unlike the screening version of the B-GSS, which assesses perceptual motor maturity and considers only distortion errors in form, Rey's test goes further when assessing planning capacity. In this sense, it is believed that the visual perception of the figures as a whole could facilitate the organization of the reproduction of the drawing from the central details, thus favoring its memorization (Alves \& Brito, 2007; Cruz et al., 2011). In the present study, the memory task indicated that it suffered the least impact from perceptual motor maturity. According to A. M. Silva et al. (2016), the way the child perceives the stimuli is directly related to the storage of information, therefore, if the child perceives the distorted figures, it is likely that memorization will also be so. In addition, it is important to consider that there are other cognitive skills that can interfere with activities that depend on perceptual maturity and immediate memory, such as attention. According to V. Sousa and Rueda (2017), in tasks that require the reproduction of figures, attention serves as a selective activation mechanism that allows the exact selection of the stimulus that will be used later.

Another observation was that, by enabling the child to be able to discriminate and select the most important information that make up a drawing, the perceptual maturity showed to be a relevant aspect for a better performance in the HFD test. Although in the Bender test, it is noted that the child draws based on what it observes, in the HFD test it draws with what it knows about the concept of human being. However, both activities encompass similar cognitive processes, as they allow complex thought structures to be formed and still require the ability to produce responses to the requests and external stimuli (Bartholomeu et al., 2012; S. L. Z. R. Silva et al., 2017; Sisto, 2005). Thus, it is believed that distortion errors in Bender's figures can influence the conceptual repertoire, impairing the quality of the drawings, and the more developed the child's perceptomotor maturity is, the more details they tend to include in the drawings of a human figure. In addition, when poorly developed, perceptual maturity can lead to possible learning difficulties, as it is linked to several cognitive functions that encompass the process of acquiring new knowledge.

It was also found that age is able to predict part of the children's performance in the screening version of the B-GSS, in the Rey Complex Figures Test and in the HFD test - Sisto scale. As previously explained, the cognitive skills underlying perceptual maturity and planning gradually improve according to the child's child development 
(M. S. Oliveira \& Rigoni, 2010; Rueda et al., 2016; Sisto, 2005). Previous studies have indicated that as the age increases, the better the children are at reproducing the figures of the instruments used in this research (Bartholomeu et al., 2102; Cruz et al., 2011; A. L. S. Oliveira et al., 2016; A. M. Silva et al., 2016; S. L. Z. R. Silva et al., 2017). However, although age is important, it is the interaction of various cognitive skills, such as language, attention, visual perception, planning, spatial and temporal orientation, motor coordination and memory that will enable and favor performance in several activities, including the learning process (A. L. S. Oliveira, 2016; Rueda et al., 2016; V. Sousa \& Rueda, 2017).

In general, the results of this study indicated that perceptual motor maturity has strong relationship with planning, immediate memory and non-verbal intelligence, suggesting that this ability tends to be essential for the development of several cognitive functions. In this perspective, it is believed that because they are related to child development, the cognitive skills assessed by the screening version of the B-GSS, the Rey Complex Figure test and the HDF test - Sisto scale tend to be of great importance for the acquisition of new knowledge and interaction with the world. As they are instruments that can be used in neuropsychological and psychological assessments, these measures complement each other and contribute to the understanding of the perceptual strategies that children use to solve different tasks. In addition, they provide the clinical or school psychologist with information that allows the use of cognitive interventions aimed at reducing possible learning difficulties.

We consider that potential limitations of this study are the fact that the instruments were not applied individually, in order to compare whether significant differences that could alter the performance of the instruments could be found. Another point is the fact that the focused skills are directly linked to the learning process and have not been related to a measure that evaluates school performance. These limitations are an invitation for new research to address these gaps and also to consider the possibility of investigating the relationship of perceptual maturity with other cognitive skills, such as attention and executive functions, as well as using samples of different regions of Brazil. Studies of this nature may facilitate the understanding of how these skills are related and present psychometric indices that validate the use of psychological instruments.

\section{References}

Alves, E. V., \& Brito, M. R. F. (2007). Relações entre a percepção da estrutura de um problema, a memória e a memória matemática [Relations between the perception of the structure of a problem, the memory and the mathematical memory]. Temas em Psicologia, 15(2), 207-215. Retrieved from http://pepsic.bvsalud.org/scielo. php?script $=$ sci_arttext\&pid=S1413-389X2007000200006
Araújo, P., \& Fernandes, R. I. (2015). O teste do Desenho da Figura Humana em crianças Angolanas: Contribuições à perspectiva da psicologia positiva [The Human Figure Drawing in Angolan children: Contributions to the perspective of positive psychology]. Psicologia: Ciência e Profissão, 35(3), 855-869. doi:10.1590/1982-3703002132013

Baddeley, A. D., Anderson, M. C., \& Eysenck, M. W. (2011). Memória [Memory] (C. Stolting, Trans.). Porto Alegre, RS: Artmed.

Bartholomeu, D., Cecato, J. F., Montiel, J. M., Machado, A. A., \& Sisto, F. F. (2012). Teste de Bender (B-SPG) e DFH-Escala Sisto: Validade por grupos contrastantes [Bender's test (B-SPG) and DFH-Scale Sisto: Validity by contrasting groups]. Estudos Interdisciplinares em Psicologia, 3(2), 241-257. Retrieved from http://pepsic.bvsalud.org/scielo.php?script $=$ sci arttext\&pid=S2236-64072012000200008

Batista, M. A., \& Gonçalves, V. A. (2016). Validade convergente entre os testes de Desenho de Silver (SDT) e Bender (B-SPG) por idade e sexo [Convergent validity between the Silver Drawing (SDT) and Bender (B-SPG) tests by age and sex]. Perspectivas Experimentais $e$ Clínicas, Inovações Biomédicas e Educação em Saúde (Pecibes), 2(2), 44-51. Retrieved from https://periodicos. ufms.br/index.php/pecibes/article/view/1369

Bender, L. (1955). Teste gestáltico visomotor [Visomotor gestalt test] (D. Carnelli, Trans.). Buenos Aires, Argentina: Paidós.

Carreras, M. A., Uriel, F., \& Fernández Liporace, M. (2013). Actualizaciones en el análisis de ítemes madurativos del dibujo de la figura humana en niños escolarizados de Buenos Aires: A revisión study [Maturational items of Human Figure Drawing in scholars from Buenos Aires]. Interdisciplinaria, 30(1), 101-118. doi:10.16888/interd.2013.30.1.6

Clarke, M., McAneney, H., Chan, F., \& Maguire, L. (2018). Inconsistencies in the drawing and interpretation of smiley faces: An observational study. BMC Research Notes, 11, 77. doi:10.1186/s13104-018-3185-0

Cohen, J. (1988). Statistical power analysis for the behavioral sciences (2nd ed.). New York, NY: Lawrence Erlbaum.

Cruz, V. L. P., Toni, P. M., \& Oliveira, D. M. (2011). As funções executivas na Figura Complexa de Rey: Relação entre planejamento e memória nas fases do teste [The executive functions in Rey's Complex Figure: Relationship between planning and memory in the phases of the test]. Boletim de Psicologia, 61(134), 17-30. Retrieved from http://pepsic.bvsalud.org/scielo.php?script=sci arttext\&pid=S0006-59432011000100003 
Fuentes, D., Malloy-Diniz, L. F., Camargo, C. H. P., \& Cosenza, R. M. (2014). Neuropsicologia: Teoria $e$ prática [Neuropsychology: Theory and practice]. Porto Alegre, RS: Artmed.

Hopkins, K. D., \& Weeks, D. L. (1990). Tests for normality and measures of skewness and kurtosis: Their place in research reporting. Educational and Psychological Measurement, 50(4), 717-729. doi:10.1177/0013164490504001

Koppitz, E. M. (1989). O teste gestáltico Bender para crianças [Bender's visomotor gestaltic test: A putting into space of figures] (R. N. Piccoli, Trans.). Porto Alegre, RS: Artes Médicas.

Muthén, L. K., \& Muthén, B. (2019). “Mplus.” Structural Equation Modeling. Retrieved from http://www. statmodel.com/SEM.shtml

Oliveira, A. L. S., Kaiser, V., Azambuja, T. O., Mallmann, L. U., Lukrafka, J. L., \& Reppold, C. T. (2016). Visual-motor maturity and executive functions in schoolchildren. Paidéia (Ribeirão Preto), 26(64), 215-223. doi:10.1590/1982-43272664201609

Oliveira, K. S., \& Wechsler, S. M. (2016). Indicadores de criatividade no desenho da figura humana [Indicators of creativity in the drawing of the human figure]. Psicologia: Ciência e Profissão, 36(1), 6-19. doi:10.1590/1982-370301682014

Oliveira, M. S., \& Rigoni, M. S. (2010). Figuras Complexas de Rey: Teste de cópia e de reprodução de memória de figuras geométricas complexas [Rey Complexes: Copy and memory replication test of complex geometric figures]. São Paulo, SP: Casa do Psicólogo.

Picard, D. (2015). Sex differences in scores on the draw-aperson test across childhood: Do they relate to graphic fluency? Perceptual and Motor Skills, 120(1), 273-287. doi:10.2466/10.27.PMS.120v10x1

Rueda, F. J. M., Sousa, V., Santos, A. A. A., \& Noronha, A. P. P. (2016). Bender - Sistema de Pontuação Gradual (B-SPG): Estudo para versão de rastreio [Bender Gradual Scoring System (B-SPG): Study for tracking version]. Psicologia: Teoria e Prática, 18(2), 117-128. doi:10.15348/1980-6906/psicologia.v18n2p117-128

Silva, A. M., Peçanha, E., Charchat-Fichman, H., Oliveira, R. M., \& Correa, J. (2016). Estratégias de cópia da Figura Complexa de Rey por crianças [Copy strategies of Rey Complex Figure by children]. Revista Neuropsicologia Latinoamericana, 8(1), 12-21. doi:10.5579/rnl.2016.0276
Silva, S. L. Z. R., Oliveira, M. C. C., \& Ciasca, S. M. (2017). Desempenho percepto-motor, psicomotor e intelectual de escolares com queixa de dificuldade de aprendizagem. [Perceptual-motor, psychomotor and intellectual performance of students with complaints of learning difficulties]. Revista Psicopedagogia, 34(103), 33-44. Retrieved from http://pepsic.bvsalud.org/scielo. php?script $=$ sci_arttext\&pid=S0103-84862017000100004

Sisto, F. F. (2005). Desenho da figura humana: Escala Sisto [Drawing of the human figure: Sisto scale]. São Paulo, SP: Vetor.

Sisto, F. F., Noronha, A. P. P., \& Santos, A. A. A. (2006). Teste gestáltico visomotor de Bender: Sistema de pontuação gradual (B-SPG) [Bender visomotor gestalt test: Graded scoring system (B-SPG)] (2nd ed.). Itatiba, SP: Vetor.

Sousa, A. B., \& Salgado, T. D. M. (2015). Memória, aprendizagem, emoções e inteligência [Memory, learning, emotions and intelligence]. Revista Liberato: Educação, Ciência e Tecnologia, 16(26), 141-151. Retrieved from https:/www.lume.ufrgs.br/bitstream/ handle/10183/132515/000982720.pdf?sequence $=1$

Sousa, V., \& Rueda, F. J. M. (2017). The relationship between perceptual motor skills and attention. Paidéia (Ribeirão Preto), 27(66), 24-32. doi:10.1590 /1982-432727662017046201704

Suehiro, A. C. B., \& Cardim, N. A. (2016). Bender-Sistema de Pontuação Gradual: uma comparação por idade, ano escolar e sexo em crianças baianas. [Bender Graded Scoring System: A comparison by age, school year and sex in Bahia Children]. Avaliação Psicológica, 15(2), 257-264. Retrieved from http://pepsic.bvsalud. org/scielo.php?script=sci_arttext\&pid $=$ S 1677 04712016000200015\&lng=pt\&tlng=pt.

Suehiro, A. C. B., Santos, A. A. A., \& Rueda, F. J. M. (2015). Desenvolvimento perceptomotor e escrita em crianças do ensino fundamental [Perception motor development and writing in elementary school children]. Psicologia Escolar e Educacional, 19(2), 369-376. doi:10.1590/2175-3539/2015/0192861

VanderWeele, T. J. (2016). Mediation analysis: A practitioner's guide. Annual Review of Public Health, 37, 17-32. doi:10.1146/annurev-publhealth-032315-021402 
Fernanda Otoni is a Ph.D. student in the Graduate Program in Psychology area of concentration in Psychological Assessment at Universidade São Francisco, Campinas-SP, Brazil.

Fabián Javier Marin Rueda is a Professor of the Universidade São Francisco, Campinas-SP, Brazil, and Centro Universitário de Brasília (UniCEUB), Brasília-DF, Brazil.

Authors' Contribution:

All authors made substantial contributions to the conception and design of this study, to data analysis and interpretation, and to the manuscript revision and approval of the final version. All the authors assume public responsibility for content of the manuscript.

Received: Oct. 23, 2018

1st Revision: Jan. 19, 2019

2nd Revision: Apr. 09, 2019

Approved: Apr. 25, 2019

How to cite this article:

Otoni, F., \& Rueda, F. J. M. (2020). Perceptive-motor maturity and its relations with planning, memory immediate and non-verbal intelligence. Paidéia (Ribeirão Preto), 30, e3031.doi:https://doi.org/10.1590/1982-4327e3031 